Journal Universitas Muhammadiyah Gresik Engineering, Social Science, and Health International Conference (UMGESHIC)

UMGCINMATIC : $1^{\text {st }}$ Rethinking Education during Covid-19 Era: Challange and Innovation

\title{
DIFFERENCES IN SELF-CONTROL FROM GENDER, AGE AND BIRTH ORDER IN NAHDLATUL ULAMA 2 STUDENTS GRESIK
}

\author{
Author \\ Choirun Nisya, Nadhirotul Laily, Ima Fitri Sholichah \\ Universitas Muhammadiyah Gresik \\ Email: choirunnisya0@gmail.com
}

\begin{abstract}
Students who can control themselves will not do wrong actions that they have experienced because they will understand that taking actions that violate the rules will get punishment consequences. Regarding gender, a person's self-control is seen from gender, including roles, behavior, preferences, and other attributes that explain a particular culture. Based on As children age, the communities that influence them increase, as well as the many social experiences they experience, children learn to respond to disappointments, dislikes, failures, and learn to control them, so that over time this self- control emerges from within itself. Birth order can affect a person's self-control in various conditions including how the individual views the role that must be carried out. This study aims to determine differences in self-control in terms of gender, age and birth order in students. This study uses a quantitative method with a population of 547 students. In this case, the researcher uses a non-probability sampling technique with a proportionate stratified random sampling technique. The sample obtained is 241 students. The method collected using a questionnaire. This study uses a summative scale measurement, with a Likert scale type with 5 (five) alternative answers. Test the validity of the scale using content validity. The scale reliability test uses the Cronbach alpha technique. The data analysis technique used the t-test data analysis technique, the Independent Samples T-

Test. The results showed that there was no significant difference between self-control with Gender, Age, and Birth Order.
\end{abstract}

Keywords: Self control, Demographic factors, Students.

\section{INTRODUCTION}

Education is an effort to advance the growth of personality, mind (intellect) and the growth and development of children (Dewantara, 1962). In accordance with the Law on the National Education System of the Republic of Indonesia No. 2 years. [1] Involving students in teaching activities at school is not easy for students who are less able to control themselves and will violate the rules and norms that have been set by the school. [2] If the student has low 
self-control, at school, especially in high school, many people often experience problems, this is due to the students' weak self-control abilities which can lead to irritability, lack of confidence and difficulty in controlling themselves. [3] Students who often face common problems at school fight, are hostile, and cheat on each other.(Intani \& Ifdil, 2018). [4] Meanwhile, students with strong self-control will show more positive behavior and are able to take responsibility, such as the responsibilities that students learn (Rianti \& Rahardjo, 2014). [5]

According to Ghufron and Rini (2011: 21), self-control describes the ability to regulate, guide, regulate and direct forms of behavior that can lead to positive consequences. Guswani and Kawuryan (2011) state that self-control is one of the supporting factors to reduce personal aggressive behavior. [6]

Self-control is a person's ability to control or be able to regulate a response in oneself to avoid unwanted behavior and increase the behavior needed to achieve a desired goal. Chaplin (2006). [7]

Judging from previous research based on the results of research conducted by (Ratnasari et al., 2020)The results showed that the higher the self-control, the higher the discipline behavior of students at school. On the other hand, the lower the self-control, the lower the student discipline behavior in the school. [8]

Gender has a significant effect on complaint behavior, indicating that there is a unidirectional relationship between gender and complaint behavior. Gender research is also supported by(Astari and Widagda K., 2014) determine the effect of gender differences and self-control on impulse buying decisions of perfume products. The results of this study that gender and self-control significantly influence the impulse buying of perfume products. [9].

This research is supported by the fact that birth order can also be a factor in the types of personal and social adjustments that individuals must make during their lives (Hurlock, 1980, pp. 33-34). Even though children have the same parents and live in the same house, they do not have the same social environment. (Fauzziyyah, Rachmawati et al., 2018).

\section{METHOD}

According to Arikunto (2002:32) that quantitative research is research that uses a lot of numbers, starting from data collection, interpretation of data and exposure of the results. This research is classified as correlational quantitative research, which aims to reveal the presence or absence of a relationship, but if there is, how close the relationship is, and whether or not the relationship is meaningful.

As the name implies, quantitative research is required to use numbers. Starting from data collection, interpretation of the data and the appearance of the results. Likewise, an explanation 
of the research conclusions will be better if it is also accompanied by tables, graphs, figures, pictures or other displays (Arikunto, 2010:27).

According to Sugiyono (2015: 80) population is a general area consisting of objects or research subjects that have characteristics that have been determined by researchers to be studied and then drawn conclusions. The population in this study is village youth who have committed juvenile delinquency at the village level totaling 119 people who have been recorded from 2015-2020. The characteristics that have been determined are as follows: 1 . The subject is a teenager, either male or female. 2, The subject has committed juvenile delinquency at the village level. 3 Subjects aged 14-19 years.

The sample in this study is part of the number and characteristics of the population (Sugiono, 2010:81). The sampling technique in this study is in accordance with the characteristics that have been determined by the researcher, namely teenagers who have committed juvenile delinquency, both boys and girls aged 14-19 years.

In this study the sampling technique used is non-probability sampling with purposive sampling technique. According to Sugiyono (2016: 85) that: "purposive sampling is a sampling technique of data sources with certain considerations." The reason for using the purposive sampling technique is because not all samples have criteria that match the phenomenon under study. Therefore, the authors chose the Purposive Sampling technique which stipulates certain considerations or criteria that must be met by the samples used in this study.

\section{RESULT AND DISCUSSION}

The validity test on the self-control scale was carried out 3 times, it can be seen that there were 28 valid items and 8 invalid items. Item is declared validbecause it meets the correlation coefficient of at least 0.25 shown Valid items from the value of $r$ which ranged from $0.25-0.68$. [28]

The self-control variable shows the results of the analysis on the instrument showing the results of the scale reliability being found to be 0.898 which means reliable. An instrument or research scale that is considered reliable should have a Cronbach Alpha reliability coefficient value of $>0.70$ or more (Suryabrata, 2012: 28). Thus the results of the reliability test show that the measuring instrument used in this study has self-control reliability as a measuring instrument. [29].

Prerequisites for conducting the t-test Must be Normality and Homogeneous Normality results obtained that the distribution of data on the male sex is $0.253>0.05$ and the female sex is $0.124>0.05$ that the data distribution meets normality. Based on the results of data processing, obtained a significance value $>0.05$, which means the sample is normally distributed. [30] HNormality results at the age of 15 years is $0.320>0.05$ and at the age of 16 years is $0.760>0.05$. The results from the age of 15 years of $0.320>0.05$ and the age of 17 
years of $0.120>0.05$, it can be interpreted that the distribution of data can meet normality. The results for 15 years old were $0.320>0.05$ and 18 years old was $0.056>$ 0.05 . The results obtained for the age of 16 years are $0.760>0.05$ and 17 years are $0.120>$ 0.05 . The results for the age of 16 years were $0.760>0.05$ and 18 years were $0.056>0.05$. The results obtained for the age of 17 years of $0.120>0.05$ and the age of 18 years of 0.056 . So it can be stated that the distribution of the data above can meet normality. Based on the results of data processing, obtained a significance value $>0.05$, which means the sample is normally distributed. [31]

The normality of the results in the eldest child was $0.995>0.05$ and the middle child was $0.084>0.05$. The results for the youngest child were $0.511>0.05$ and the eldest child was 0.955 . The results obtained in the youngest child of $0.511>0.05$ and the middle child of 0.084 , it can be interpreted that the distribution of data can meet normality with a significant level of 0.05 . Based on the results of data processing, obtained a significance value $>0.05$, which means the sample is normally distributed. [32]

In the homogeneity test, the researcher used Levene's test because this test can be used to test homogeneous variance on data that is not normally distributed. The data can be declared homogeneous with a significant level of $<0.05$. [33] Levene's test value on gender is indicated by sig (p value) $0.026>0.05$, which means that it can be declared homogeneous. Based on the results of data processing, obtained a significance value $>0.05$, it can be concluded that gender has the same or homogeneous variance. [34]

Homogeneous results for age in group 1 are indicated by sig ( $\mathrm{p}$ value) 0.8660 .05 . In the second group, it is indicated by sig ( $\mathrm{p}$ value) $0.168>0.05$. In the third group, it is indicated by sig ( $\mathrm{p}$ value) 0.206 . In the fourth group, it is indicated by sig ( $\mathrm{p}$ value) 0.156 $>0.05$. In the 5th group, it is indicated by sig ( $\mathrm{p}$ value) $0.203>0.05$. In the 6th group, it is indicated by sig ( $\mathrm{p}$ value) $0.856>0.05$, which means the variance of the 6 groups is homogeneous. Based on the results of data processing, obtained a significance value $>0.05$, it can be concluded that age has the same or homogeneous variance. [35Homogeneous results in birth order Levene's test value in group 1 showed sig ( $\mathrm{p}$ value) $0.861>0.05$. In the second group, it showed sig ( $\mathrm{p}$ value) $0.658>0.05$. The third group showed sig ( $\mathrm{p}$ value) $0.678>$ 0.05. Of the 3 groups can be declared homogeneous. Based on the results of data processing, obtained a significance value $>0.05$, it can be concluded that the birth order has the same variance or is homogeneous. [36]

In the results of the gender $t$ test, it was found that there was no significant difference in self-control between men and women $(\mathrm{p}<0.695)$. Judging from Cohen'ds to see the difference, it shows that the magnitude of the effect is $0.067>0.5$. This shows that the hypothesis is that there is no difference in self-control between the sexes. [37]

In the t-test the results of age grouped into 6 , it is known that there is no difference in 893 
self-control with age. In group 1 there was no significant difference in self-control between the ages of $15-16$ years $(\mathrm{p}<0.686)$. Judging from Cohen'ds to see the difference, it shows that the magnitude of the effect is $0.075>0.5$. In group 2 there was no significant difference in self-control between the ages of $15-17$ years $(\mathrm{p}<0.257)$. Judging from Cohen'ds to see the difference, it shows that the magnitude of the effect is $0.207>0.5$. In group 3 there was no significant difference in self-control between the ages of $15-18$ years $(\mathrm{p}<0.588)$. Judging from Cohen'ds to see the difference, it shows that the magnitude of the effect is 0.122 $>0.5$. In group 4 there was no significant difference in self-control between the ages of 1617 years $(\mathrm{p}<0.079)$. Judging from Cohen'ds to see the difference, it shows that the effect size is $0.281>0.5$. In group 5 there was no significant difference in self-control between the ages of 16-18 years ( $\mathrm{p}<0.796$ ). Judging from Cohen'ds to see the difference, it shows that the effect size is $0.054>0.5$. In group 6 there was no significant difference in Self-Control between the ages of 17-18 years ( $\mathrm{p}<0.128)$. Judging from Cohen'ds to see the difference, it shows that the effect size is $0.312>0.5$. So it can be concluded that the 6 groups did not meet, meaning that there was no significant difference in self-control with age. [38] Judging from Cohen'ds to see the difference, it shows that the effect size is $0.054>0.5$. In group 6 there was no significant difference in Self-Control between the ages of 17-18 years $(\mathrm{p}<0.128)$. Judging from Cohen'ds to see the difference, it shows that the effect size is $0.312>0.5$. So it can be concluded that the 6 groups did not meet, meaning that there was no significant difference in self-control with age. [38] Judging from Cohen'ds to see the difference, it shows that the effect size is $0.054>0.5$. In group 6 there was no significant difference in Self- Control between the ages of $17-18$ years $(\mathrm{p}<0.128)$. Judging from Cohen'ds to see the difference, it shows that the effect size is $0.312>0.5$. So it can be concluded that the 6 groups did not meet, meaning that there was no significant difference in self-control with age. [38]

In the t-test the results of birth orderIf these groups are grouped into 3, it is known that there is no difference between Self-Control and Birth Order. In group 1 there was a significant difference in Self-Control between the eldest-middle children $(\mathrm{p}<0.839)$. Judging from Cohen'ds to see the difference, it shows that the magnitude of the effect is $0.027>0.5$. In the second group, there was no significant difference in Self-Control between the eldest and youngest children $(\mathrm{p}<0.077)$. Judging from Cohen'ds to see the difference, it shows that the effect size is $0.749>0.5$. In the third group, there was no significant difference in self-control between the middle-youngest children ( $\mathrm{p}<0.077$ ). Judging from Cohen'ds to see the difference, the effect size is 0.745 . This means that from the 3 groups that cannot fulfill it, there is no significant difference in self-control with birth order. [37]

\section{CONCLUSION}

Based on the research data, it can be concluded as follows: 
a. Item validity results are declared valid because it meets the correlation coefficient of at least 0.25 shown Valid items from the value of $r$ which ranged from $0.25-0.68$. [38]

b. The results of the scale reliability were found to be 0.898 , which means reliable. An instrument or research scale that is considered reliable should have a Cronbach Alpha reliability coefficient value of $>0.70$ or more. [39]

c. Researchers used Levene's test because the test can be used to test homogeneous variance on data that is not normally distributed. The data can be declared homogeneous with a significant level of $<0.05$. Gender is indicated by sig ( $\mathrm{p}$ value) $0.026>0.05$. Age in group 1 is indicated by sig ( $\mathrm{p}$ value) $0.866>0.05$. In the second group, it is indicated by sig ( $\mathrm{p}$ value) $0.168>0.05$. In the third group, it is indicated by sig ( $\mathrm{p}$ value) 0.206 . In the fourth group, it is indicated by sig (p value) $0.156>$ 0.05 . In the 5 th group, it is indicated by sig (p value) $0.203>0.05$. In the 6th group, it is indicated by sig ( $\mathrm{p}$ value) $0.856>0.05$. The Birth Order in group 1 showed sig ( $\mathrm{p}$ value) $0.861>0.05$. In the second group, it showed sig ( $\mathrm{p}$ value) $0.658>0.05$. The third group showed sig ( $\mathrm{p}$ value) $0.678>0.05$. Based on the conclusion that the Homogeneous test has the same or homogeneous variance. [40]

d. To see the difference between significant variables $\mathrm{p}<0.05$, it is known that there is no significant difference in self-control between men and women $(p<0.695)$. In group 1 there was no significant difference in self-control between the ages of 1516 years ( $\mathrm{p}$ <.686). In group 2 there was no significant difference in self-control between the ages of $15-17$ years $(p<0.257)$. In group 3 there was no significant difference in self-control between the ages of $15-18$ years $(p<0.588)$. In group 4 there was no significant difference in self-control between the ages of 16-17 years $(\mathrm{p}<0.079)$. In group 5 there was no significant difference in self-control between the ages of 16-18 years $(\mathrm{p}<0.796)$. In group 6 there was no significant difference in Self-Control between the ages of $17-18$ years $(p<0.128)$. Based on the conclusion that the $\mathrm{t}$ test $\mathrm{HO}$ is accepted, $\mathrm{Ha}$ is rejected because it is significant at $\mathrm{p}$ $<0.05$. [41]

\section{REFERENCES}

Duwi Priyatno (2010). "5 Hours of Data Processing Learning with SPSS 19". Yogyakarta: Andi

Eliza, M. (2013). The Relationship Between Self-Control and Academic Achievement Student. Accompanied not published. Yogyakarta. Sanata University Psychology Dharma.

Ghufron, M. \& S, Rini, R. (2014). Psychological Theories. Yogyakarta : Ar-Ruzz Media. 
Harahap, JY (2017). The Relationship Between Self Control And Internet Dependence In The Digital Library Of The Medan Regional Library. JOURNAL OF EDUCATION: Journal of Counseling Guidance, 3(2), 131.

Harahap, M. (2016). 195156-ID-essence-student-in-perspective-pe. 1(113), 140-155. Herlina. (2013). Adolescent Development (Age 11/12 - 18 years). Addressing Child And Adolescent Problems, 1-5.

Intani, CP, \& Ifdil, I. (2018). The relationship of self-control with student achievement. EDUCATIO Journal: Indonesian Education Journal, 4(2), 65.

Journal of Personality 72:2, April 2004.

Karina, NKG, \& Herdiyanto, YK (2019). Differences in self-regulation in terms of birth order and gender of Balinese adolescents. Udayana Journal of Psychology, 6(1), 849-858.

Marsela, RD, \& Supriatna, M. (2019). Self Control: Definition and Factors. Journal of Innovative Counseling, 3(2), 65-69.

Ningsih, R. (2018). The Effect of Self-Control on Teenagers' Discipline Behavior. 2(2), 04. Pertiwi, Yuline, P. (2012). Adolescent Development Tasks at SMA Negeri 1 Sejangkung. 1-11. Growth, J., Child, P., \& Early, U. (2018). 42 Edukids 15 (1), 2018. 15(229), 42-58.

Putra, N., \& Giantari, I. (2014). The Influence of Complaining Attitudes and Gender on Complaint

Behavior at the Faculty of Economics and Business, Udayana University Denpasar.

Ratnasari, E., Noor, T., \& Dewayani, E. (2020). The relationship of self-control with student discipline behavior at school. 2014, 259-264.

Rini, R., \& Muslikah, M. (2020). The Relationship of Family Roles and Self-Control with Student Ditching Behavior. Educational Counseling "Journal of Guidance and Counseling," 4(1), 17-34.

Sa'adah L, M., Martadani, L., \& Taqiyuddin, A. (2021). Analysis of Employee Performance Differences at PT Surya Indah Food Multirasa Jombang. Journal of Research Innovation

3) $1,2,3.2(2)$.

Sari, S., Yusri, \& Said, A. (2017). Student Self-Control in Learning and Student Perception of BK Teacher's Efforts to Improve Self-Control. Indonesian Teacher Research Journal, 2(1), 32-37.

Sugiyono, (2016). Quantitative, Qualitative, and R\&D Research Methods. Bandung : Alphabeta.

Sujana, IWC (2019). Functions and Objectives of Indonesian Education. Adi Widya: Journal of Basic

Education, 4(1), 29. 
Source JASP version 15

Sumitro, \& Imam Yuliadi. (2019). The Role of Education in Building Social Awareness of the Bima

Community. Journal of Social Sciences Education, 9(2), 149-154.

Supriani. (2018)Comparison of the Application of Outdoor Learning Activities with Indoor Learning Activities on the Level of Student Creativity in Learning Pai Di Sdn 15 Jolle, Soppeng Regency. Accompanied not published. Makassar: Tarbiyah and Teacher Training

Suyono, A. (2018). Differences in Love in terms of Demographic Factors (Gender, Age, Marriage Age, and Education Level) in Married Civil Servants in Purwokerto. Dissertation is not published. Purwokerto. Psychology University of Purwokerto.

Syafi'i, A., Marfiyanto, T., \& Rodiyah, SK (2018). Study of Student Achievement in Various Aspects and Influencing Factors. Journal of Educational Communication, 2(2), 115.

Syaribulan, S., \& Nurdin, N. (2017). Gender Geneology in Female Dried Fish Makers.

Equilibrium: Journal of Education, 3(1), 96-105.

Tangney, Baumeister, and Boone (2004). High Self-Control Predicts Good Adjustment, Less

Pathology, Better Grades, and Interpersonal Success.

Tarigan, MA (2016). The Relationship Between Self-Control and Aggressive Tendencies in

Adolescents at SMK Negeri 3 Yogyakarta. 1-19.

Titisari, HTD (2018). The relationship between self-adjustment and self-control with delinquent behavior in students of SMA Muhammadiyah 1 Jombang. Psychodimensia, 16(2), 131.

Triyanto, E. (2010). The Experience of Adolescent Puberty in Phenomenological Studies in Purwokerto. Journal of Ners, 5(2), 147-153.

Widyastari, D., Atrizka, D., Ramadhani, B., \& Damanik, DS (2020). Academic Procrastination Seen From Self-Control in Ar-Rahman Medan Private High School Students. Journal of Educational Research, Psychology and Health (JP3K), 1(2), 82-91.

Wulandari, A. (2014). Growth Characteristics of Adolescent Development and Its Implications for Health and Nursing Problems. Journal of Pediatric Nursing, 2, 39-43. 